\title{
Compensatory renal growth and mitochondrial function: the influence of warm ischemia and reperfusion ${ }^{1}$
}

\author{
Hipertrofia renal compensatória e função mitocondrial: influência da isquemia quente e \\ reperfusão
}

\author{
Silvio Tucci Jr', Carlos Augusto Fernandes Molina ${ }^{\mathrm{II}}$, Adauto José Cologna ${ }^{\mathrm{III}}$, Haylton Jorge Suaid ${ }^{\mathrm{IV}}$, Luis Fernando \\ Tirapelli $^{\mathrm{V}}$, Fábia Martins Celini ${ }^{\mathrm{VI}}$, Antonio Carlos Pereira Martins ${ }^{\mathrm{VII}}$ \\ I MD, PhD, Associated Professor, Division of Urology, Department of Surgery and Anatomy, Ribeirão Preto Faculty of Medicine, \\ University of São Paulo, Brazil. \\ II MD, Fellow PhD degree, Department of Surgery and Anatomy, Ribeirão Preto Faculty of Medicine, University of São Paulo, Brazil. \\ III MD, PhD, Department of Surgery and Anatomy, Ribeirão Preto Faculty of Medicine, University of São Paulo, Brazil. \\ Iv MD, PhD, Associated Professor, Division of Urology, Department of Surgery and Anatomy, Ribeirão Preto Faculty of Medicine, \\ University of São Paulo, Brazil. \\ v MD, PhD, Department of Surgery and Anatomy, Ribeirão Preto Faculty Medicine, University of São Paulo, Brazil. \\ vi Fellow Master degree, Department of Pediatric, Ribeirão Preto Faculty Medicine, University of São Paulo, Brazil.

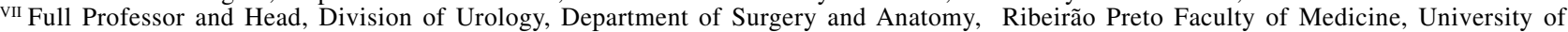 \\ São Paulo, Brazil.
}

\begin{abstract}
Purpose: To evaluate the influence of ischemia/reperfusion injury on renal compensatory growth (CGR) and mitochondrial function. Methods: Forty five Wistar rats were divided in 3 groups: Control Group (GC) - 21 rats were submitted to a sham laparotomy and sacrificed at $1^{\text {st }}$ ( 6 rats $)$ and $7^{\text {th }}$ (15 rats) postoperative days to evaluate the dry weight of both kidneys and their growth during 1 week (6 rats) and to quantify mitochondrial respiration (9 rats); Group 1 (G1) - 12 rats underwent right nephrectomy and were sacrificed 7 days later for analysis of renal mitochondrial function (6 rats) and dry weight (6 rats). Group 2 (G2) - renal warm ischemia for 60 minutes followed by right nephrectomy was performed in 12 rats; they were sacrificed 7 days later to evaluate renal mitochondrial function (6 rats) and dry weight (6 rats). Results: Dry weight (mg) of left kidneys at $7^{\text {th }}$ day: GC $-219 \pm 18, G 1-281 \pm 23$ and G2 - 338 \pm 39 (GCxG1 p $\left.<0.01 ; G C x G 2 p<0.001 ; G 1 x G 2 p<0.01\right)$. State 4 mitochondrial respiration rate and respiratory control ratio $(\mathrm{RCR})$ were similar in all groups $(\mathrm{p}>0.05)$. State 3 respirations $(\mathrm{mM} / \mathrm{min} / \mathrm{mg})$ in GC, G1 and G2 was respectively: $99 \pm 23,132 \pm 22$ and $82 \pm 44$ (p<0.02; the only statistical difference noted was between groups $\mathrm{G} 1 \mathrm{xG} 2-\mathrm{p}<0.05)$. Conclusions: Following unilateral nephrectomy $\mathrm{CRG}$ is associated with an increase in state 3 of mitochondrial respiration. Renal ischemia/reperfusion injury enhances the CRG provoked by unilateral nephrectomy but such enhancement seems independent on mitochondrial respiration.
\end{abstract}

Key words: Ichemia. Reperfusion. Mitochondria. Compensatory Renal Growth.

\section{RESUMO}

Objetivo: Avaliar a influência da lesão de isquemia/reperfusão na hipertrofia renal compensatória (HRC) e na função mitocondrial. Métodos: 45 ratos Wistar foram divididos em três grupos: Grupo Controle (GC) - 21 ratos submetidos apenas à laparotomia e sacrificados no $1^{\circ}$ dia $(6$ ratos $)$ e $7^{\circ}$ dia pós-operatório (15 ratos) para avaliar o peso seco de ambos os rins e seu crescimento durante uma semana (6 ratos) e quantificar a função mitocondrial ( 9 ratos); Grupo 1 (G1) - 12 ratos submetidos à nefrectomia direita e sacrificados após 7 dias para análise da função mitocondrial renal (6 ratos) e peso renal seco (6 ratos); Grupo 2 (G2) - isquemia renal quente durante 60 minutos no rim esquerdo seguida da nefrectomia direita foi realizada em 12 ratos, que foram sacrificados após 7 dias para avaliação da função mitocondrial (6 ratos) e peso seco (6 ratos). Resultados: peso seco (mg) do rim esquerdo no $7^{\circ}$ dia: $\mathrm{GC}=219 \pm 18 ; \mathrm{G} 1=281 \pm 23$ e G2=338 \pm 39 (GCxG1 p<0,01; GCxG2 p<0,001; G1xG2 p<0,01). O estado 4 da função mitocondrial e a Razão de Controle Respiratório (RCR) foram semelhantes em todos os grupos ( $\mathrm{p}>0,05)$. O estado 3 da respiração mitocondrial $(\mathrm{mMO} / \mathrm{min} / \mathrm{mg})$ no $\mathrm{GC}$, G1 e $\mathrm{G} 2$ foi, respectivamente: 99 $\pm 23,132 \pm 22$ e $88 \pm 44$ ( $\mathrm{p}<0,02$; a única diferença estatística foi observada entre os grupos $\mathrm{G} 1 \times \mathrm{xG} 2-\mathrm{p}<0,05)$. Conclusões: após nefrectomia unilateral a HRC está associada ao aumento do estado 3 da respiração mitocondrial. A lesão de isquemia/ reperfusão renal aumenta a HRC estimulada pela nefrectomia unilateral, mas este aumento parece independer da respiração mitocondrial.

Descritores: Isquemia. Reperfusão. Mitocondria. Hipertrofia Renal Compensatória.

1. Research performed at Department of Surgery and Anatomy, Division of Urology, Ribeirão Preto Faculty of Medicine, University of São Paulo (USP), Brazil. 


\section{Introduction}

In mammalian species, when renal mass is reduced significantly, a series of compensatory morphological, physiological, and biochemical changes occur in the remaining functional renal mass. ${ }^{1}$ Compensatory renal growth (CRG) depends mainly on cell hypertrophy but cell hyperplasia also occurs. ${ }^{2-5}$ The CRG following unilateral nephrectomy of the adult animal does not involve formation of new nephrons while CRG resulting from unilateral nephrectomy of fetuses during the period of neprogenesis seems to be associated with nephron endowment. ${ }^{6}$ Several reports explore the influence of age, chemotherapy and/or radiotherapy and malnutrition on $\mathrm{CRG}^{7-10}$ The mechanisms responsible for CRG are not known with certainty, although a number of biochemical and molecular changes have been observed that could be involved such as several growth factors, interleukins and the rennin-angiotensin system. ${ }^{11-}$ 15

The beginning of renal transplantation programs arouses a new opportunity for studying CRG in association with renal ischemia/reperfusion injury. Upon hypoxic injury, the depletion of ATP causes mitochondrial dysfunction, and accumulation of intracellular sodium, calcium and reactive oxygen species. ${ }^{16-19}$ Subsequently, multiple enzyme systems including proteases, nitric oxide synthases, phospholipases and endonuclease are activated and responsible for cytoskeleton disruption, lipid peroxidation, membrane damage, and DNA degradation, and eventually cell death. Ischemia/reperfusion injury also activates complement, cytokines, and chemokines, which are cytotoxic themselves, but also attract leukocytes into the ischemic area to cause further damage. ${ }^{20-24}$

The aim of this research was to evaluate the influence of ischemia/reperfusion injury on renal compensatory growth (CGR) and mitochondrial function.

\section{Methods}

Forty five male Wistar rats, weighing 180-200g, were divided at random in 3 groups: Control group (GC) (renal weight) -21 rats were submitted to a sham laparotomy and sacrificed at $1^{\text {st }}$ ( 6 rats) and $7^{\text {th }}$ (15 rats) postoperative days to evaluate the dry weight of both kidneys and their normal growth during 1 week (6 rats) and to quantify mitochondrial function (9 rats). Group 1 - 12 rats underwent right nephrectomy and sacrifice 7 days later. Mitochondrial function was studied in the left kidneys of 6 animals and the left renal dry weight was determined in the remaining 6 rats. Group 2 - the left renal artery of 12 rats was clamped to promote left renal warm ischemia for 60 minutes followed by right nephrectomy. At the $7^{\text {th }}$ postoperative day they were sacrificed to harvest the left kidney to evaluate mitochondrial function (6 rats) and the dry weight (6 rats).
For surgical procedures all rats were anesthetized by an intraperitoneal injection of thionembutal $(50 \mathrm{mg} / \mathrm{kg})$. After harvesting the kidneys all animals were sacrificed by an overdose of anesthetic.

To determine the dry weight the kidneys were placed on a piece of aluminum foil previously weighed, and kept within a stove at $58^{\circ} \mathrm{C}$. The kidneys were weighed every 24 hours for the time required to achieving a steady weight, and afterward they were cooled at room temperature in a dryer vacuum chamber. To determine the final weight we subtracted the weight of the aluminum foil.

To extract renal mitochondria the kidneys were washed with cool saline $(0.15 \mathrm{M} \mathrm{NaCl})$ in a Becker recipient right after the nephrectomy. The kidneys were homogenized (Potter-Ehlvejem homogenizer), 3 cycles of 3 minutes with an interval of 1 minute between the cycles, in $10 \mathrm{ml}$ of a solution containing sucrose $(250 \mathrm{mM})$, EGTA $(1 \mathrm{mM})$, BSA $(0.2 \%$ of volume) and Tris- $\mathrm{HCl}(10 \mathrm{mM}), \mathrm{pH} 7.2$. The homogenate was centrifuged at $750 \mathrm{G}$ for 3 minutes. The supernatant containing the mitochondria was aspirated and centrifuged at $15,000 \mathrm{G}$ for 10 minutes. The pellet was suspended in the above mentioned buffer without EGTA, and centrifuged at 15,000G for 10 minutes. The pellet was suspended in $0.5 \mathrm{ml}$ of buffer without EGTA. All steps were carried out at $4^{\circ} \mathrm{C}$. The protein content of mitochondria suspension was quantified by the biuret method with addition of $1 \%$ collate. $^{24}$

The mitochondrial respiratory function was measured immediately after isolation by polarographic analysis at $30^{\circ} \mathrm{C}$. Briefly, mitochondria $(1 \mathrm{mg})$ were added to $1.4 \mathrm{ml}$ of solution containing $250 \mathrm{mM}$ sucrose, $8.5 \mathrm{mM}$ $\mathrm{KH}_{2} \mathrm{PO}_{4}, 10 \mathrm{mM}$ EDTA, $2 \mathrm{mg} / \mathrm{ml}$ BSA and 10mM Tris- $\mathrm{HCl}$, $\mathrm{pH}$ 7.4. Mitochondrial respiration was initiated by addition of succinate $(5 \mathrm{mM}$ final concentration) plus rotenone (2 $\mu \mathrm{M})$, and oxidative phosphorylation was initiated by addition of $400 \mathrm{mM}$ ADP. $\mathrm{O}_{2}$ consumption recordings allowed the calculation of V3 [rate of state 3 (ADPstimulated) respiration], of V4 [rate of state 4 (non-ADPstimulated) respiration] and of the respiratory control ratio $(\mathrm{RCR}=\mathrm{V} 3 / \mathrm{V} 4)$. The oxygen uptake of V3 and V4 was expressed in nmol oxygen $/ \mathrm{min} / \mathrm{mg}$ mitochondrial protein. As controls of mitochondrial respiratory function we used the kidneys of 9 rats of the control group.

Data were analyzed by the software program GraphPad Prism 4. Continuous variables were compared by the two-tail one-way ANOVA and by the Tukey-Kramer multiple comparisons test. A p value $<0.05$ was set as significant.

\section{Results}

The dry weight of kidneys of normal rats from Control Group rose in the period of 7 days and there was no difference between right and left kidneys (Table 1). 
TABLE 1 - Dry weight (mg) of rat's kidneys submitted to sham laparotomy (Control Group).

\begin{tabular}{cccc}
\hline $\begin{array}{c}\text { Right kidney }\left(1^{\text {st }} \text { day }\right) \\
\text { Mean } \pm \text { SD }\end{array}$ & $\begin{array}{c}\text { Left kidney }\left(1^{\text {st }} \text { day }\right) \\
\text { Mean } \pm \text { SD }\end{array}$ & $\begin{array}{c}\text { Right kidney }\left(7^{\text {th }} \text { day }\right) \\
\text { Mean } \pm \text { SD }\end{array}$ & $\begin{array}{c}\text { Left kidney }\left(7^{\text {th }} \text { day }\right) \\
\text { Mean } \pm \text { SD }\end{array}$ \\
\hline $180.6 \pm 11.8$ & $178.4 \pm 10.8$ & $205.9 \pm 10.3$ & $219.1 \pm 18.5$ \\
\hline
\end{tabular}

Double-tail one-way ANOVA $p>0.05$

The results of the dry weight of the left kidney at $\quad 7^{\text {th }}$ day following the surgery are displayed in the Figure 1.

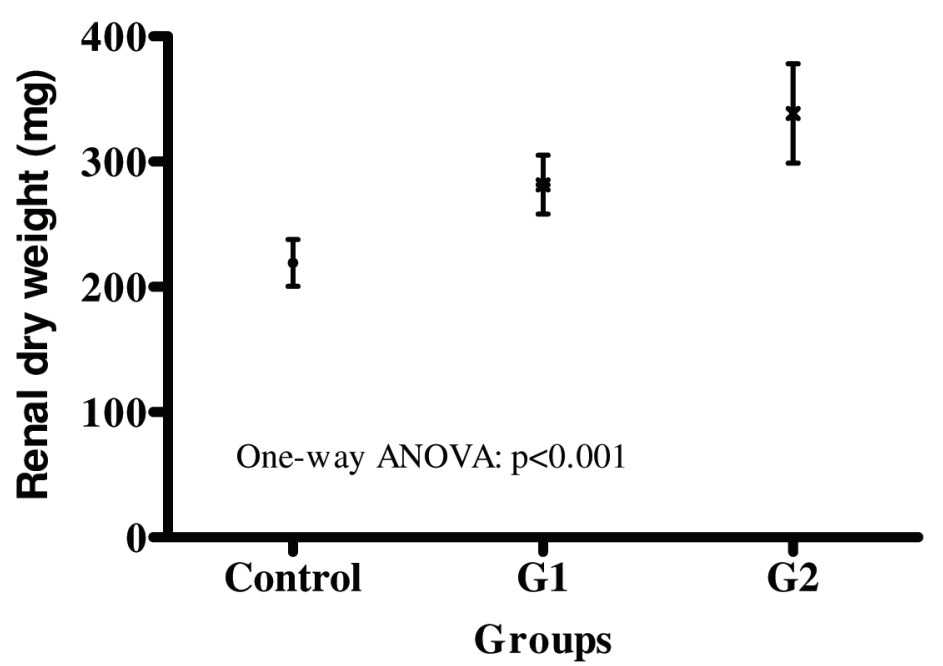

FIGURE 1 - Dry weight of the left kidney $(M e a n \pm S D)$ of the animals of all groups. Tukey-Kramer test p: control x G1 (unilateral nephrectomy) - <0.01; control x G2 (ischemia/reperfusion plus contralateral nephrectomy) - $<0.001 ; \mathrm{G} 1$ x G2 - <0.01.

The results of mitochondrial respiration rate are

shown in Table 2. The only significant difference was in state 3 respiration rates.

TABLE 2 - Mitochondrial respiration in all groups of rats at $7^{\text {th }}$ days of follow-up.

\begin{tabular}{lcccc}
\hline Group & $\mathrm{N}$ & State $3^{*}$ & State $4 *$ & RCR \\
\hline Control (sham) & 9 & $99.9 \pm 23.0(\mathrm{a})$ & $31.7 \pm 9.9(\mathrm{~d})$ & $3.2 \pm 0.7(\mathrm{~g})$ \\
1 (nephrectomia) & 6 & $132.9 \pm 20.6(\mathrm{~b})$ & $37.5 \pm 6.6(\mathrm{e})$ & $3.5 \pm 0.5(\mathrm{~h})$ \\
2 (ischemia plus nephrectomy) & 6 & $82.2 \pm 44.4(\mathrm{c})$ & $34.0 \pm 11.7(\mathrm{f})$ & $2.6 \pm 0.6(\mathrm{i})$ \\
One-way ANOVA p & & $<0.02$ & 0.45 & 0.05 \\
\hline
\end{tabular}

* Oxygen: $\mathrm{mM} / \mathrm{min} / \mathrm{mg}$ protein; the only significant Tukey-Kramer test $\mathrm{p}$ was $\mathrm{b}$ x c $-<0.05$. 


\section{Discussion}

Our data showed that unilateral nephrectomy gives rise to CRG similar to previous reports..$^{2-5,25,26}$ But, our demonstration that renal warm ischemia enhances the CRG due to unilateral nephrectomy was not reported previously. It is not clear how the ischemia/reperfusion injury stimulates the CRG or how and when such challenge influences the release of growth factors.

During the first days of CRG there is an increase in the number and or volume of mitochondria ${ }^{27,28}$ which suggest that the kidney undergoing CRG requires a higher demand of energy. ${ }^{29}$ Thus, in such condition one could expect that mitochondria would consume more oxygen. This was confirmed by the increase of the mitochondrial state 3 respiration rates that we observed in Group 1 (unilateral nephrectomy). However, in Group 2 (unilateral nephrectomy plus ischemia/reperfusion of the remaining kidney) the changes of states 3 and 4 of mitochondrial respiration rates, as well as the RCR, did not reach statistical significance in comparison with the Control Group although they showed a tendency to be lower. The mitochondria from left kidneys of animals from Group 2 were challenged in two ways: $1^{\text {st }}$ ) renal ischemia/reperfusion injury that should decreases mitochondrial ATP generation and oxygen consume as reported elsewhere ${ }^{16-19}$, and $2^{\text {nd }}$ ) stimuli for undergoing CRG that should increase mitochondrial ATP generation and oxygen consume. ${ }^{29}$ As a net result at the $7^{\text {th }}$ day, Group 2 exhibited an enhancement of the renal growth that was not associated with an increase in mitochondria respiration. Thus, in Group 2 the CRG seemed to be not associated with higher mitochondrial respiration rates, which possibly means that a higher demand of energy or more oxygen consume does not take a central role on $\mathrm{CRG}$.

\section{References}

1. Kaufman JM, Dimeola HJ, Siegel NJ, Lytton B, Kashgarian M, Hayslett JP. Compensatory adaptation of structure and function following progressive renal ablation. Kidney Int.1974;6:107.

2. Shirley DG. Developmental and compensatory renal growth in guinea pig. Biol Neonate. 1976;30:169-80.

3. Fine LG. The biology of renal hypertrophy. Kidney Int. 1986;29:619-34.

4. Han SW, Rha KH, Choi SK, Lee MS. Cellular proliferation during compensatory renal growth in neonatal rats using flow cytometry, Nephron. 2002;90:224-6.

5. Liu B, Preisig PA. Compensatory renal hypertrophy is mediated by a cell cycle-dependent mechanism. Kidney Int. 2002;62:1650-8.

6. Douglas-Denton R, Moritz KM, Bertram JF, Wintour EM. Compensatory renal growth after unilateral nephrectomy in the ovine fetus. J Am Soc Nephrol. 2002;13:406-10.

7. Celsi G, Jacobson B, Aperia A. Influence of age on compensatory renal growth in rats. Pediatr Res. 1986;20:347-50.
8. Lutteneger TJ, Gooding CA, Fickenscher LG. Compensatory renal hypertrophy after treatment for Wilm’s tumor. Am J Roentg. 1975;125:348-51.

9. Larsson L, Aperia A, Wilton P. Effect of normal development on compensatory renal growth. Kidney Int. 1980;18:29-35.

10. Weissgarten J, Modai D, Berman CM, Galperin E, Averbukh Z. Proliferative responses of mesangial cells to growth factors during compensatory versus dietary hypertrophy. Nephron. 2000;85:24853.

11. Yoo KH, Thornhill BA, Forbes, MS, Chevalier RL. Compensatory growth due to neonatal ureteral obstruction: implication for clinical studies. Pediatr Neprhol. 2006;21:368-75.

12. Weissgarten J, Berman S, Efrati S, Rapaport M, Cohn M, Modai D, Averbukh Z. Apoptosis and proliferation of mesangial cells isolated from kidneys undergoing compensatory growth following contralateral nephrectomy: role of the rennin-angyotensyn system. Med Sci Monit. 2007;13:16-23.

13. Joly E, Nonclerq D, Caron N, Mertens J, Flamion B, Toubeau G, Kramp R, Bouby N. Differential regulation of aniotensyn II receptors during renal injury and compensatory hypertrophy in the rat. Clin Exp Pharmacol Physiol. 2005;32:241-8.

14. Sinuani I, Averbukh Z, Gitelman I, Rapoport MJ, Sandbank J, Albeck M, Srendi B, Weissgarten J. Mesangial cells initiate compensatory renal tubular hypertrophy via IL-10-induced TGF-beta secretion: effect of the immunomodulator AS101 on this process. Am J Physiol Renal Physiol. 2006;291:384-94.

15. Hauser P, Kainz A, Perco P, Bergmeister H, Mitterbauer C, Schwarz C, Regele HM, Mayer B, Meyer TW, Oberbauer R. Transcriptional response in the unaffected kidney after contralateral hydronephrosis or nephrectomy. Bosn J Basic Med Sci. 2006;6:46-9.

16. Brezis M. Cellular mechanism of acute ischemic injury in the kidney. Ann Rev Med. 1993;44:27-37.

17. Netto JMB, Tucci S Jr, Cologna AJ, Suaid HJ, Martins ACP, Molina CAF, Roselino JES. Chlorpromazine and mitochondrial function in kidney ischemia-reperfusion. Acta Cir Bras. 2001;16:36-40.

18. Castro-Silva O, Centurion S, Pacheco EG, Brisotti JL, Oliveira AF, Sasso KD. Basics aspects of the ischemia reperfusion injury and of the ischemic preconditioning. Acta Cir Bras. 2002;17:96-100.

19. Willhelm M, Pratschke J, Laskowski I, Tilney NL. Ischemia and reperfusion injury. Transplant Rev. 2003;17:140-57.

20. Bonventre JV, Zuk A. Ischemic acute renal failure: an inflammatory disease? Kidney Int. 2004;66:4805.

21. Eschwege P, Paradis V, Conti M, Holstege A, Richet F, Deteve J, Menager P, Legrand A, Jardin A, Bedossa P, Benoit G. In situ detection of lipid peroxidation by-products as markers of renal ischemia injuries in rat kidneys. J Urol. 1999;162:553-7.

22. Gueler F, Gwinner W, Schwrz A, Haller H. Longterm effects of acute ischemia and reperfusion injury. Kidney Int. 2004;66:523-7. 
23. Paller MS. The cell biology of reperfusion injury in the kidney. J Invest Med. 1994;42:632-9.

24. Kaplan RS, Pedersen PL. Characterization of phosphate efflux pathways in rat liver mitochondrial. Biochem J. 1983;212:279-88.

25. Sun L, Langer WJ, Devish K, Lane PH. Compensatory kidney growth in estrogen receptor-alpha null mice. Am J Physiol Renal Physiol. 2006;290:F319-23.

26. Tucci S Jr, Badra AV, Rodrigues AA, Suaid HJ, Cologna AJ, Martins ACP. Estudo comparative da hipertrofia renal compensatória após nefrectomia ou obstrução uretral total em ratos. Acta Cir Bras. 1997;1:29-31.
27. Johnson HA, Amendola F. Mitocondrial proliferation in compensatory growth of the kidney. Am J Pathol. 1969;54:35-45.

28. Hwang S, Bohman R, Navas P, Norman JT, Bradley T, Fine LG. Hipertrophy of renal mitochondria. J Am Soc Nephrol. 1990;1:822-7.

29. Lash LH, Putt DA, Horky SJ $3^{\text {rd }}$, Zalups RK. Functional and toxicological characteristics of isolated renal mitochondria: impact of compensatory renal growth. Biochem Pharmacol. 2001;62:383-95.

\section{Correspondence:}

Silvio Tucci Junior

Department of Surgery and Anatomy

Ribeirão Preto Faculty of Medicine, University of São Paulo

Conflict of interest: none

14.048-900 Ribeirão Preto, São Paulo, Brazil.

Financial source: FAEPA

Phone/Fax: (+55) 16 3602-2593

stucci@ convex.com.br

\section{How to cite this article:}

Tucci S Jr, Molina CAF, Cologna AJ, Suaid HJ, Tirapelli LF, Celini FM, Martins ACP. Compensatory renal growth and mitochondrial function: the influence of warm ischemia and reperfusion. Acta Cir Bras [serial on the Internet], 2008; 23 Suppl 1. Available from URL: http://www.scielo.br/acb.

\section{Comments:}

The authors present an experimental study in which they investigated possible interferences of ischemia/reperfusion (I/R) injury with the process of compensatory growth of the contralateral kidney after nephrectomy. Compensatory renal growth occurred in the control group but not in the experimental groups studied and the I/R injury did not seem to interfere with this process. However, ADP-activated mitochondrial respiration (state 3 ) was significantly reduced during I/R, in agreement with literature data. The interesting finding of this investigation is that I/R injury does not prevent growth of the remaining kidney. The experimental model was designed with high scientific rigor, thus validating the method employed and the results obtained.

\section{Orlando de Castro-e-Silva}

Full Professor and Head, Division of Digestive Surgery, Department of Surgery and Anatomy, Ribeirão Preto Faculty of Medicine, Brazil.

\section{Comments:}

Studies on ischemia/reperfusion alterations are of importance, especially when correlated to the physiopathology in organ transplants. Animal experimental models contribute to its understanding and to the use of certain drugs in these conditions. In this investigation, the authors studied the compensatory hypertrophy after unilateral nephrectomy in one group of animals, and in another group, hypertrophy was evaluated after 60 minutes warm ischemia followed by contra lateral nephrectomy. The renal mitochondrial respiration function was analyzed in both groups. Renal hypertrophy was detected in both groups when compared to controls but results of mitochondrial respiration between groups was only different in state 3. Similar nephrectomy -induced renal hypertrophy is reported in the literature, but not that it is increased during reperfusion/ ischemia. Unfortunately, no clear explanation is available to explain this finding. The study also shows that there is no correlation between reperfusion hypertrophy and mitochondrial respiration. The results in this paper are interesting as it concerns the physiopathology phenomenon occurring during reperfusion/ischemia besides opening new ways to evaluate these conditions, mainly the role of altered mitochondrial respiration.

\section{Miguel Moyses Neto}

MD, Nephrology Division, Department of Clinical Medicine, Ribeirão Preto Faculty of Medicine, University of São Paulo, Brazil. 